\title{
Contributions of the cryosphere to mountain communities in the Hindu Kush Himalaya: a review
}

\author{
Aditi Mukherji $^{1}$ - Anna Sinisalo ${ }^{1}$ - Marcus Nüsser ${ }^{2} \cdot$ Rodney Garrard $^{3} \cdot$ Mats Eriksson $^{4}$
}

Received: 23 January 2018 / Accepted: 6 March 2019 / Published online: 23 March 2019

(C) The Author(s) 2019

\begin{abstract}
There is a growing recognition of the contribution of the cryosphere to human societies. This is especially important in the Hindu Kush Himalaya (HKH), where poverty and vulnerability are high and climate change impacts on the cryosphere are strong. However, there is a lack of synthesized knowledge about the contributions of the cryosphere to high mountain communities. This paper uses a cryosphere service framework - a derivative of the ecosystem service concept - to classify different goods and services provided by the cryosphere. Case studies were selected using an adapted systematic review methodology. These studies were then synthesized and examined through the lens of critical political ecology. The review shows that while the cryosphere provides a whole range of goods and services for mountain communities, not all of these are well documented. Material services like the supply of water for irrigation and agriculture, and disservices such as disasters, are better documented than non-material services like the spirituality of landscapes. The majority of the case studies do not use an interdisciplinary lens. While some studies on irrigation discuss the physical basis and human organization of irrigation, the literature on disasters mostly focuses on the physical processes and at most generalized loss and damage assessments. Further, most case studies do not use the critical epistemologies needed to examine how politics, power, and intersectionality influence societal responses to changes in the cryosphere. The paper suggests that future studies adopt interdisciplinary collaboration to understand human impacts and adaptive responses through critical political ecology frameworks.
\end{abstract}

Keywords Cryosphere contributions · Cryosphere services · Disservices and disasters $\cdot$ Interdisciplinary frameworks $\cdot$ Political ecology

\section{Introduction}

The cryosphere plays an important role in regulating the earth's climate. Some components of the cryosphere, such as glaciers and permafrost, are key climate change indicators. In recent years, there has been an increasing recognition of the

Electronic supplementary material The online version of this article (https://doi.org/10.1007/s10113-019-01484-w) contains supplementary material, which is available to authorized users.

Aditi Mukherji

aditimukherji15@gmail.com

Anna Sinisalo

Anna.Sinisalo@icimod.org

Marcus Nüsser

marcus.nuesser@uni-heidelberg.de

Rodney Garrard

garrard.rodney@gmail.com role of the cryosphere in climate regulation and change, as well as its contribution to the lives and livelihoods of mountain communities. This has manifested, among others, in the commissioning of a special report on the cryosphere by the Intergovernmental Panel on Climate Change (IPCC), which is scheduled to be published in 2019. The cryosphere is an
Mats Eriksson

mgi_eriksson@yahoo.se

1 International Centre for Integrated Mountain Development (ICIMOD), GPO Box 3226, Kathmandu, Nepal

2 Department of Geography, South Asia Institute, Heidelberg University, Heidelberg, Germany

3 Institute of Geography, University of Bern, Bern, Switzerland

4 Stockholm International Water Institute (SIWI), Stockholm, Sweden 
important component of the Hindu Kush Himalaya (HKH), and the region is often referred to as the Third Pole or the Water Towers of Asia (Mukherji et al. 2015) as it has the largest deposits of ice and snow outside the two poles. Until about a decade ago, there was a dearth of peer-reviewed knowledge on both the extent of climate change in the HKH and its impact on various components of the cryosphere. Since then, a number of studies have documented the extent of climate change in various parts of the HKH (Cannon et al. 2014; You et al. 2017) and the impact of this change on glaciers (Bolch et al. 2012; Kääb et al. 2015; Yao et al. 2012; Zhao et al. 2014), river flows (Immerzeel et al. 2012; Lutz et al. 2014, 2016), and to some extent snow and permafrost (Gao et al. 2016; Wang et al. 2016).

While our knowledge about the physical basis of cryospheric change has expanded considerably in recent years, and much of this knowledge has been synthesized from an $\mathrm{HKH}$-wide perspective, there has been a lack of commensurate attempts to synthesize the existing literature on the contributions of the cryosphere to the high mountain societies who live in the vicinity (within approximately $30 \mathrm{~km}$ ) of cryospheric components like glaciers, ice, snow, permafrost, and glacier lakes and, most importantly, who make direct use of these components for their livelihoods or are directly affected by cryosphere-related hazards. Some work has been carried out on the impacts of cryospheric changes on human societies as a whole in the HKH region, where basins, like the Indus, were identified to be more critically dependent on ice, snow, and glaciers than other basins (Kaser et al. 2010). However, much of this body of work has focused on the downstream impacts in the plains (Moors and Stoffel 2013; Nepal et al. 2014; Siderius et al. 2013), leaving us with less understanding about the impacts of cryospheric change on high mountain communities.

Given this knowledge gap, the first objective of this paper is to review the existing literature and provide a synoptic picture of the contributions of the cryosphere to high mountain communities in the HKH. This is done through a systematic review of case studies. The second objective is to view this synthesized knowledge in the context of conceptual frameworks emanating from political ecology that incorporates power, politics, and intersectionality, in order to identify gaps in the way contributions of the cryosphere are analyzed and understood.

\section{Integrated frameworks for understanding human-environment interactions}

The concept of human-environment interaction has been a core theme of human geography since the beginning (Kates 2002). Thus, the need to use integrated approaches for better understanding of human-environment interactions in high mountain regions has also been felt from early on. Early integrative attempts were based on deterministic explanations of causality between altitudinal (Brush 1976) and latitudinal (Goldstein and Messerschmidt 1980) zonation together with other factors in the biophysical environment such as solar radiation and aspect (Whiteman and May 1985). These factors were used to explain variations in crop choice and productivity in mixed mountain agricultural systems. Some of the early scholarship included "culture" in the form of ethnic and tribal identity and were termed "geoecological" interactions (Allan 1985). These deterministic explanations held sway for a while and led to influential integrative narratives such as the theory of Himalayan degradation, which was later proven to be scientifically inaccurate (Blaikie and Muldavin 2004; Ives 2004). In recent years, there has been a rekindling of interest in linking cryosphere research with societal needs (Qin et al. 2017). One of the outcomes of this has been the emergence of the applied concept of a cryosphere service function (CSF) framework (De Xiao et al. 2015), largely adapted from the concept of ecosystem services (ES), which in turn emerged as an outcome of the Millennium Ecosystem Assessment launched in 2001 (Chaudhary and McGregor 2018). Four categories of cryosphere services (CS) have been identified: supply, societal and cultural, regulation, and habitat (De Xiao et al. 2015). Cryosphere-related disasters (Mach et al. 2014) are identified as a cryosphere disservice. Interestingly, just as the cryosphere community caught on to the concept of ES, the concept itself started undergoing changes through global processes, and a new concept-nature's contributions to people (NCP) emerged in the latest round of the Intergovernmental Science-Policy Platform on Biodiversity and Ecosystem Services (IPBES). NCP can be both positive and negative and therefore helps capture "disservices" like hazards and disasters. NCP also places more emphasis on contributions that cannot necessarily be measured and quantified in conventional financial terms but are greatly valued by different stakeholders, especially indigenous societies (Díaz et al. 2018).

Even before the formal use of the term CS in 2015 (De Xiao et al. 2015), Garrard et al. (2012) talked about ES in the mountain context, and later, Palomo (2017) documented the impact of climate change on ES in high mountain regions and identified knowledge gaps vis-à-vis the Global South. However, most of these frameworks, including the CS, have a positivist bias and have been critiqued on several grounds. The ES framework has been criticized (Kull et al. 2015) due to its positioning as a value-neutral concept, while the trade-offs and choices implicit in its framing and application are ignored. This criticism emerges from scholars from the political ecology tradition who pay particular attention to issues of political 
power and struggles over access to natural resources and how these are mediated through various intersectionalities of power, wealth, and status (Muldavin 2008).

More recent approaches emanating from the socioecological system framework have avoided deterministic explanations by recognizing the dynamic nature and feedback loops inherent in human-environment interactions. Given that water-related benefits (and disbenefits) are significant in the cryosphere, socio-ecological frameworks that aim for a more nuanced understanding of the complexity within water management systems and focus on interactions, feedback loops, and dynamics between the natural and human spheres have emerged in the form of the sub-discipline of socio-hydrology (Nüsser et al. 2012; Sivapalan et al. 2012). However, in spite of their attempts to forge a holistic and interdisciplinary understanding, these approaches have also been criticized for not paying enough attention to issues of social heterogeneity and power (Fabinyi et al. 2014).

Starting from the critical perspective of political ecology, the hybrid nature of human-water relations has also been explored in the form of hydrosocial cycles. Under this umbrella, the importance of biophysical forces is recognized, but a greater emphasis is placed on the role of politics and culture in shaping them (Boelens 2014; Linton and Budds 2014). Due to the social stratification of all societies (Sanderson 2018), some people are more vulnerable while others have more options to cope with change depending on social position, power, and access to alternative livelihood options. While sociohydrology and hydrosocial cycles seem to be similar concepts with similar aims for integration, in reality, they have quite different ontological, epistemological, and methodological underpinnings (Wesselink et al. 2017). The hydrosocial perspective has a stronger constructivist stance towards critical human-water relations and gives agency to mountain communities not as mere victims of environmental conditions but in actively shaping the environment. In the penultimate section of the paper, we examine the case studies from the lens of critical political ecology and see if issues of power, position, and intersectionality are considered adequately when documenting the contributions of the cryosphere to high mountain communities.

\section{Criteria for the selection of case studies}

The twin objectives of this paper are to review and paint a synoptic picture of the current state of contribution of cryosphere services to mountain communities in the $\mathrm{HKH}$ and to examine these contributions through the lens of critical political ecology and its derivative hydrosocial cycles, as discussed in the previous section. To start, we used CS as a way of organizing all the goods and services provided by the cryosphere (Fig. 1).
The selection of case studies for review was partially informed by the method of systematic review (Waddington et al. 2012). Clear inclusion and exclusion criteria were developed. Systematic reviews have been used elsewhere in the cryosphere for understanding the human dimensions of climate change (Ford et al. 2012). Three major academic databases were searched: Scopus, Web of Science, and Google Scholar. The search terms of the first group were cryosphere, glacier, snow, ice, permafrost, and glacier (also glacial) lake. The keywords of the second group were society, economics, tourism, irrigation, socioeconomic impact, disaster, flood, migration, religion, livelihoods, climate change, adaptation, mitigation, and community perception. A third group of keywords was used to delimit the studies to the geographical area of the HKH: Afghanistan, Bhutan, China, India, Myanmar, Nepal, Pakistan, Indus, Ganges, Brahmaputra, Himalaya, Hindu Kush, and Karakoram. Query formulation was done by selecting one term each from the three groups and combining them with Boolean AND. All permutations and combinations of queries were carried out, duplicates were removed, and all identified references were then transferred to Mendeley. This search strategy yielded 1544 articles.

The authors then scanned the records using the following inclusion/exclusion criteria. First, case studies were restricted to areas which are in the vicinity of glaciers, ice, snow, permafrost, and glacier lakes and where direct use is made of cryospheric components for livelihoods. Areas in the midhills and further downstream in the plains were excluded even if they benefit indirectly from cryosphere services like provision of water or energy. Second, only those services which are directly used by humans and those (dis)services which directly affect humans were considered for this paper, while fully acknowledging that the cryosphere offers a range of goods and services of indirect value such as regulation of overall climate and habitat parameters.

Using these criteria, a total of 78 case studies were identified, of which 21 dealt with supply services (agriculture and irrigation); 3 with regulation services; 18 with societal and cultural services; 12 with habitat services; and 24 with disservices (Fig. 2 and Supplementary Table 1). The largest number of studies were from the Trans-Himalaya (21) and Central Himalaya (17), followed by the Qinghai-Tibetan Plateau (16), Karakoram (12), Eastern Himalaya (9), and Northwestern Himalaya (3). Three of the studies were located in Bhutan, 17 in China, 21 in India, 22 in Nepal, and 15 in Pakistan. In addition, 10 case studies on the perceptions of climate change by cryosphere-dependent communities were reviewed and summarized. The majority $(\sim 90 \%)$ of the studies identified using the selection criteria were papers from peer-reviewed journals. 


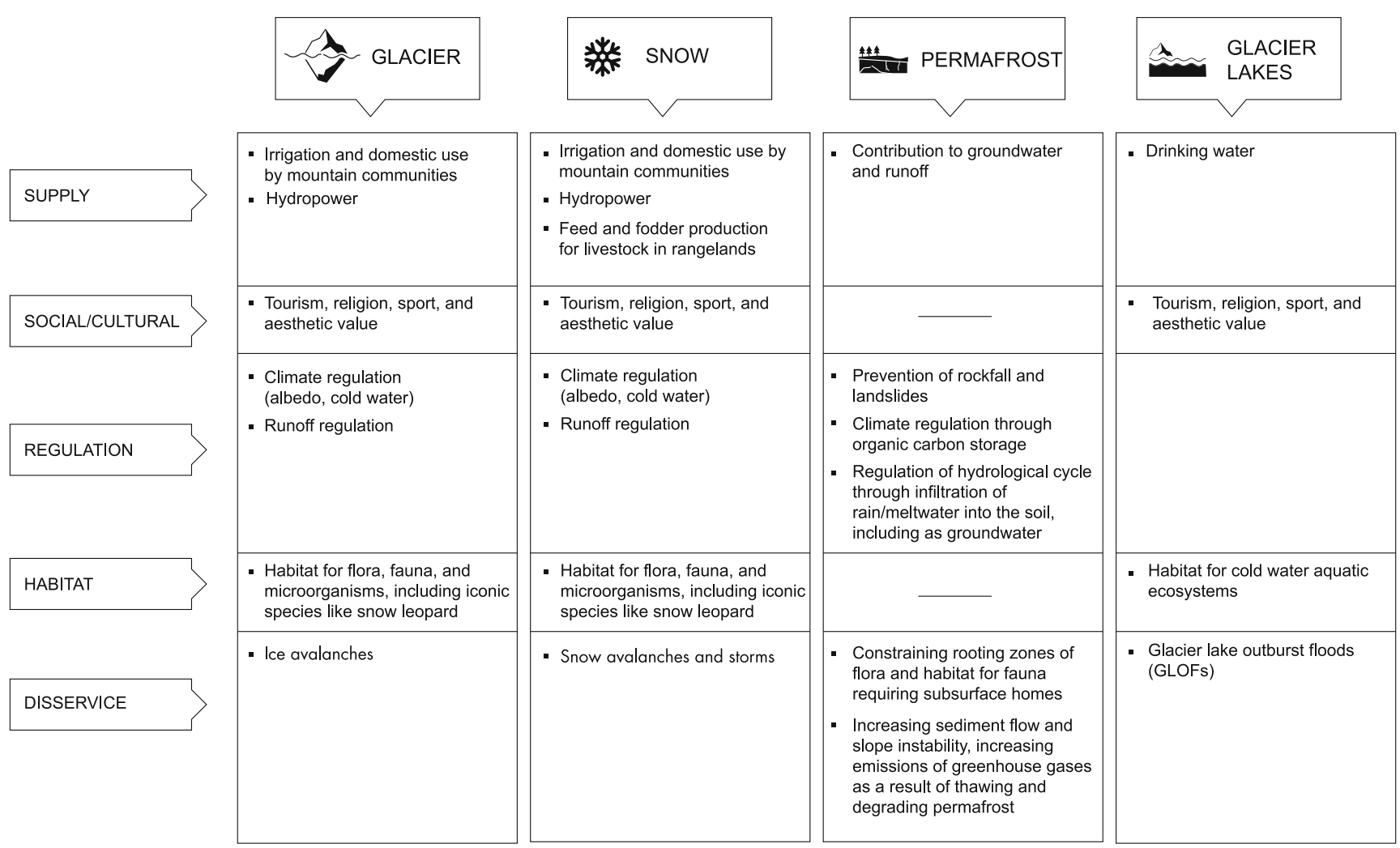

Fig. 1 Cryosphere components and associated services and disservices in the vicinity of mountain communities

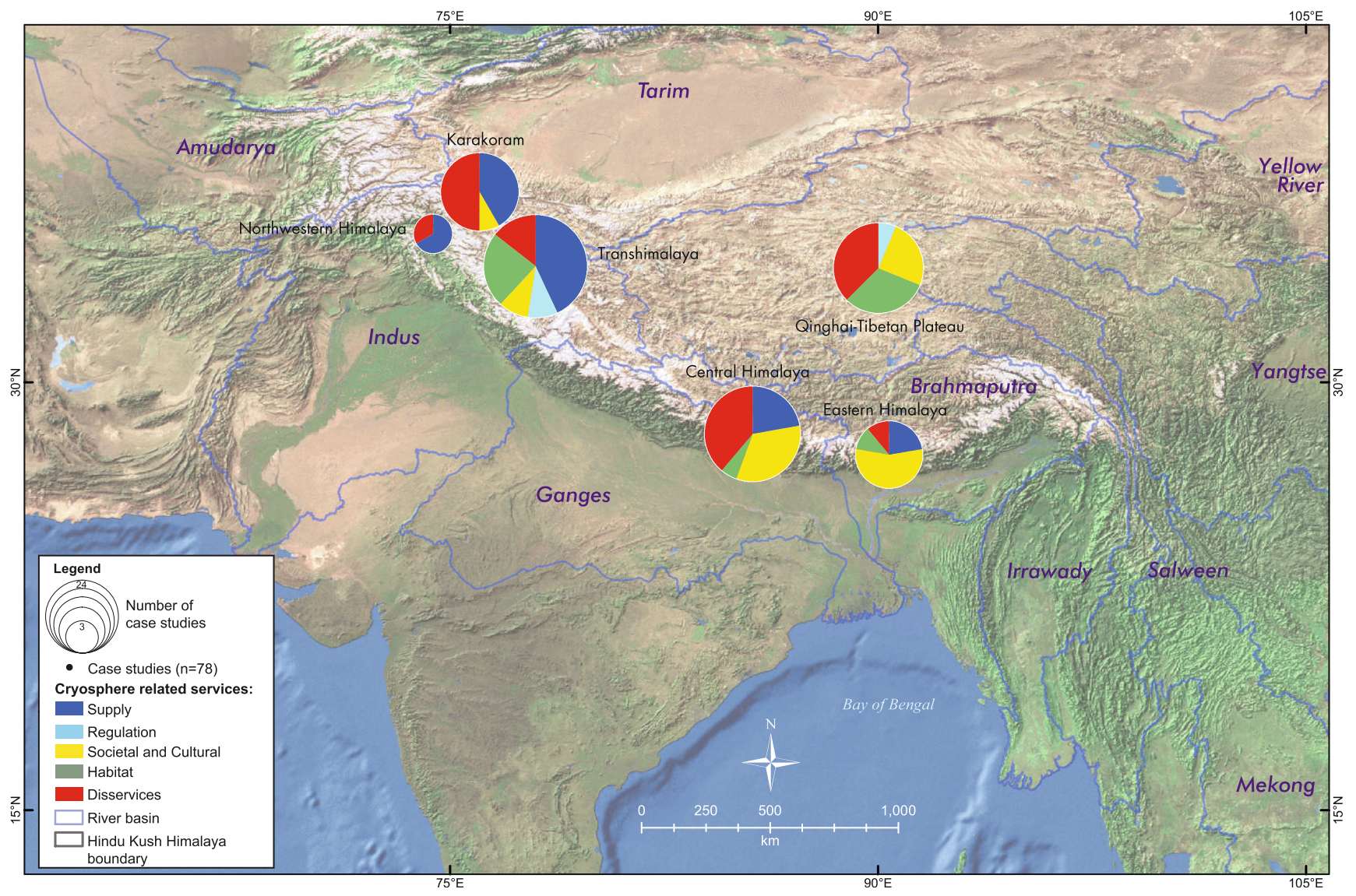

Fig. 2 Location of case studies on cryosphere-related services in the Hindu Kush Himalaya 


\section{The changing cryosphere and perception of local communities}

During the last decade, several high-quality studies from the natural sciences have helped fill the knowledge gap vis-à-vis the impacts of climate change on various components of the cryosphere in the HKH. However, only a relatively small number of studies have emerged that encapsulate community perceptions of these changes. This section sums up the advances in our knowledge about the changing cryosphere from both a natural and a social science perspective.

It is increasingly clear that capping global warming below $1.5^{\circ} \mathrm{C}$ as laid out in the Paris Agreement is highly ambitious (Bodansky 2016). Furthermore, recent studies show that even if the rest of the world manages to keep the temperature rise below the $1.5^{\circ} \mathrm{C}$ threshold, the rise will still be between $0.3^{\circ} \mathrm{C}$ and $0.7^{\circ} \mathrm{C}$ higher than this in the HKH due to elevationdependent warming (Lutz et al. 2018). This has clear implications for the HKH cryosphere. The recent IPCC report on $1.5^{\circ} \mathrm{C}$ also pointed out that some of the high elevation and mountainous areas like the Tibetan Plateau face the additional risk of an increase in extreme weather events (HoeghGuldberg et al. 2018).

Overall, glaciers have retreated, thinned, and lost mass in almost all parts of the HKH except the Karakoram and Kunlun Shan (Brun et al. 2017), and even with the ambitious $1.5^{\circ} \mathrm{C}$ target, $36 \pm 7 \%$ of the ice mass is projected to be lost by the end of the century (Kraaijenbrink et al. 2017). Both the number and surface area of glacier lakes have increased since 1980 (Shrestha et al. 2017; Zhang et al. 2015) posing an increasing risk for high mountain communities. Snow cover trends averaged over the last three decades are still relatively short to detect climatic signals, but they indicate generally earlier snowmelt seasons. Further, there is evidence of an overall decrease in the water content of the snow cover (expressed as snow water equivalent), notwithstanding increases in some regions (Smith and Bookhagen 2018). Permafrost thaw is expected to accelerate in the HKH (Guo et al. 2012, 2016) with increasing infrastructure development and is driving diverse permafrost-related impacts on vegetation, water quality, geohazards, and livelihoods (Gruber et al. 2017) and on the hydrological cycle in general, as well as leading to increased greenhouse gas emissions to the atmosphere (Mu et al. 2018). The contributions of cryosphere components to river runoff have a high spatial variability in the HKH and are expected to change with climate change. In the Indus and Brahmaputra basins, for example, annual glacier runoff is projected to rise until roughly the middle of the century and steadily decline thereafter. However, considerable small-scale intra-basin variability exists within the region. This variability is attributed to a combination of differences in glacier size and a projected increase in summer precipitation in monsoon-dominated regions (Huss and Hock 2018; Lutz et al. 2014).
In contrast to this burgeoning body of scientific studies on climate change and its impacts on the cryosphere, there are relatively few studies that look into the impacts of cryospheric changes on mountain communities, even though these are recognized as being among the most vulnerable people in the world (McDowell et al. 2013). The explanation lies in part in the issue of scale. Climate change projections are made at a regional or basin scale, while the impacts are felt at the local scale, which cannot be modeled as effectively. To bridge the gap between climate change studies at a basin level and understanding of people's adaptation strategies at a local level, a few studies have looked at the perceptions of local communities. We found 10 such climate perception studies. While the local communities' perception of climate change was uniform throughout - rising temperatures in winter, less rain and snowfall, unpredictable rainfall events, accelerated melting of snow and glaciers - the impacts of these changes were much more site- and context-specific (Table 1).

\section{Cryosphere services and disservices: case studies}

\section{Supply services}

Supply services, now categorized as material contributions under the new NCP terminology (Díaz et al. 2018), are better documented than most other services because of their tangibility. The main supply services discussed are irrigation, agriculture, livestock, and hydropower.

\section{Irrigation}

Irrigation services are one of the best documented of all cryosphere services, possibly because of the uniqueness of the high mountain cryosphere-supported irrigation systems. However, many of the studies, especially those from the Karakoram, are more than 20 years old, and there are knowledge gaps on the societal aspects of high mountain irrigation in recent years.

There are two major features of the natural environment in mountains controlling the extent and spread of agriculture. The first is the elevation-controlled temperature regime, which limits agriculture to elevations below approximately 4000 masl; the second is the limitations imposed by local terrain, as only relatively flat land or land which can be terraced can be used for farming. However, it is the third feature - water supply - that makes snow- and glacier-fed irrigation in the Karakoram and Trans-Himalaya unique. In the Karakoram, for example, much of the precipitation falls as snow in winter at elevations above 3500 masl, while there is not much precipitation at lower elevations, which tend to be arid. The plentiful water stored in the snow and glaciers above 
Table 1 People's perception of the impact of climate change on various cryosphere services

\begin{tabular}{|c|c|c|}
\hline Study area & Cryosphere services which are impacted & Source \\
\hline Khumbu, Nepal & $\begin{array}{l}\text { Supply services - reduced water access leading to lower crop yields, affecting agriculture } \\
\text { and hydropower } \\
\text { Societal and cultural services — less water for tourists, affecting tourism }\end{array}$ & $\begin{array}{l}\text { McDowell et al. } \\
\text { (2013) }\end{array}$ \\
\hline Manang District, Nepal & Societal and cultural services - change in traditional agropastoral practices, tourism & $\begin{array}{l}\text { Konchar et al. } \\
\text { (2015) }\end{array}$ \\
\hline Rara and Langtang, Nepal & $\begin{array}{l}\text { Habitat services - changes in phenology of tree and agricultural crops, upward migration } \\
\text { of species }\end{array}$ & $\begin{array}{l}\text { Lamsal et al. } \\
\text { (2017) }\end{array}$ \\
\hline Mustang, Nepal & $\begin{array}{l}\text { Supply/regulation services - decreased stream flows } \\
\text { Societal and cultural services- tourism affected due to less snow, perception that local } \\
\text { deities have been offended }\end{array}$ & $\begin{array}{l}\text { Manandhar et al. } \\
\text { (2012); } \\
\text { Becken et al. } \\
\quad(2013)\end{array}$ \\
\hline Mt. Everest, Nepal & $\begin{array}{l}\text { Supply services - water supplies affect cash crops } \\
\text { Habitat services - more insect and pest attacks, mosquitoes noted only after } 2008 \\
\text { Societal and cultural services - elderly women and monks believe local deities have been } \\
\text { offended due to non-religious behavior of tourists from outside }\end{array}$ & Sherpa (2014) \\
\hline $\begin{array}{l}\text { Thimphu, Bumthang, Paro, and } \\
\text { Wangdue Districts, Northern Bhutan }\end{array}$ & $\begin{array}{l}\text { Supply services - less snow, less water availability for yaks and livestock, less milk } \\
\text { production } \\
\text { Habitat services — more wildlife attacks on yak herds }\end{array}$ & $\begin{array}{l}\text { Wangchuk and } \\
\text { Wangdi (2018) }\end{array}$ \\
\hline Ladakh, India & $\begin{array}{l}\text { Habitat services - upward migration of apple orchards, birds like geese and Brahminy } \\
\text { kites found throughout the year }\end{array}$ & $\begin{array}{l}\text { Le Masson and } \\
\text { Nair (2015) }\end{array}$ \\
\hline Sikkim, India & $\begin{array}{l}\text { Habitat services - late flowering of prominent plants and species migration, and } \\
\text { introduction of new crops like vegetables }\end{array}$ & Ingty (2017) \\
\hline Hunza and Karakoram, Pakistan & Supply services - increased crop risks due to colder summers and erratic precipitation & Gioli et al. (2014 \\
\hline
\end{tabular}

is diverted for irrigation in the areas below when it melts in early summer, giving rise to the phenomenon of "verdant agricultural oases" in otherwise arid landscapes (Butz 1989, p. 35 ).

Hopar is a small community in northern Pakistan which derives its irrigation from seasonal snow and ice patches. Here, there are three challenges related to the physical basis of irrigation: uncertainty in timing of the start of meltwater delivery; low water temperature, which is harmful for crop growth; and high sediment load. These problems are solved through adjustments in the cropping calendar and/or installation of appropriate infrastructure (Butz 1989). However, the greatest structural challenge comes from extreme weather events and landslides which can destroy irrigation canals (McDonald 1989), while the greatest challenge to the social basis of irrigation is the opening up of remote areas like Hopar to regional trade and migration (Kreutzmann 1993). Some high mountain irrigation systems depend on a number of cryospheric components, and some are more prone to hazards than others. For example, irrigation systems in Passu, Borith, and Ghulkin villages in Hunza are dependent on glaciers, glacier lakes, glaciofluvial streams, seasonal snowmelt, and even snow-fed springs. The irrigation system in Passu is the most well-endowed, while the systems in Ghulkin and Borith are exposed to a wider range of risks like glacier retreat, glacial(er) lake outburst floods (GLOFs), overtopping of lateral moraines, and erosion of channel intakes (Parveen et al. 2015).
In the Shigar Valley in Gilgit Baltistan, Pakistan, irrigation systems that draw from snowmelt and high-altitude springs have been documented as a part of village revenue records dating from 1913 AD (Hill 2014, 2017). The irrigation infrastructures - channels called hrkong or hrka and reservoirs called zings - are owned by the entire community, and there are detailed written rules on the use of water, maintenance of infrastructure, and conflict resolution. These rules have more or less stood the test of time. In the 1980s, the Aga Khan Rural Support Programme (AKRSP) started investing in the creation of new irrigation channels in the area, but the results were mixed - with many channels abandoned after the project period. Overall, water scarcity is not very common in the Shigar Valley, leading to fewer irrigationrelated disputes, but the impacts of climate change on irrigation have not yet been documented in any of the case studies.

In the extreme arid climate of Ladakh, India, cultivation is only possible with irrigation from glacier meltwater, which is sourced and channeled from several kilometers away. Due to the high elevation of the villages and short growing season, only one cropping season is possible (Nüsser et al. 2012). Takeda and Yamaguchi (2015) have documented the intricate working of one such irrigation system in the Domkar valley in Ladakh. Here, water is spread on the fields just before the onset of winter, this then freezes, and thawed soil moisture is used for irrigation in early spring. In general, the agriculture season commences in April and ends by September. However, over the years, winters have become shorter and winter snow 
accumulation has dwindled, thereby limiting the amount of winter snowmelt available before the beginning of the cropping season in April. Faced with the threat of further curtailing of an already short growing season, a Ladakhi engineer created the first "artificial glacier" in 1987 (Nüsser and Baghel 2016). These horizontally stacked glaciers are created at lower elevations and start melting earlier than natural glaciers, thus helping provide early irrigation. While useful as a local adaptation measure (Shaheen et al. 2013), the use of the term "artificial glacier" has been contested in recent literature (Nüsser et al. 2018).

The naturally arid districts of Manang and Mustang lie in the rain shadow Trans-Himalayan zone in Nepal. In Manang, agriculture is only possible on the southward slope and is dependent on irrigation channels which draw water from glacier and snowmelt streams. Here, rising summer temperatures and reduced winter precipitation have created uncertainties in the timing and quantity of water delivery. The coping mechanisms identified include changes in crop choice - away from wheat to less water-consuming barley; shifting of crop fields from terraced valley slopes to valley bottoms where the main flow of the river can also be used for irrigation; and shifting to other occupations, like tourism (Aase et al. 2010). In Mustang, the physical basis of irrigation is much the same as elsewhere in the region. However, as a result of a historical legacy of unequal land rights and property structures related to polyandry and primogeniture, the rules for water access and distribution are highly inequitable (Chalaune 2009). Mustang has been experiencing an increase in summer temperature and decrease in winter precipitation. Farmers have adapted to these changes in several ways by changing water distribution rules to ration the limited water supply; tapping additional water sources and constructing new storage infrastructure; shifting to orchard crops like apples; adopting new water management practices that focus on water-saving techniques; abandoning land which is distant from the main village; and finally, resorting to seasonal out-migration to supplement family income (Prem and Jagat 2013). As elsewhere, landslides and glacier-related hazards pose further threats to the physical basis of irrigation (Fort 2014).

All the case studies on irrigation demonstrate three main features. First, the physical basis of irrigation is snow, ice, and glacier melt. Second, these irrigation systems are as much socially constructed as they are constructed through the sitespecific physical geography. This leads to context-specific rules for water sharing, allocation, and distribution. These rules are likely to become more detailed and stringent as levels of water scarcity increase. Finally, most of the irrigation systems are facing pressure both from climate change, manifested mostly in the form of glacier retreat and extreme weather events and from the impacts of demographic change and the opening up of remote economies. Therefore, further modifications in these systems need to be analyzed through the lens of socio-ecological change. Indeed, among the different case studies, it is the ones on irrigation that have received the most interdisciplinary treatment, but some of the studies that look at social relationships around irrigation infrastructure are more than two decades old.

\section{Supporting livestock in rangelands and other agricultural services}

Cryospheric components also support extensive rangelands, which in turn support large herds of livestock. However, these services are not as well documented. In Shimsal in the Karakoram, herding norms are closely entwined with the physical environment and are an integral part of a societal ethos that enables people to make sustainable use of their pastures (Butz 1996). In Hunza, pastoralism is on the decline in response to multiple changes - both climatic and societal (Kreutzmann 1993), while in the Rupal Valley, it is on the rise due to a different combination of similar factors (Nüsser and Clemens 1996). None of the more recent studies looks at the impacts of climate change on pastoral communities in the $\mathrm{HKH}$

In Himachal Pradesh in India, apple production has been hit by a decrease in snowfall and increase in temperature, forcing apple producers to move their orchards to higher elevations (Basannagari and Kala 2013). In Khawa Karpo on the Tibetan Plateau, glacier retreat is one of many factors that has affected decisions around cropping systems. Other factors, such as elevation of a village and how well it is connected by road, have also led to discernible changes in land use and land cover (Salick et al. 2005). However, except for the study in Shimsal, which unpacks the societal norms, none of the studies looked at the differential impacts on different groups of people.

\section{Hydropower}

The governments of Bhutan, China, India, Nepal, and Pakistan are currently transforming the upper reaches of the HKH river basins into a sub-continental hydroelectric powerhouse in Asia at an unprecedented pace (Nüsser 2017), thereby intensifying tensions related to water competition, hydroelectric water management, transboundary conflicts, new water technologies, and economic development (Huber and Joshi 2015). Research on cryospheric change and its impacts on hydropower generation, water storage, dry season flows, and related socio-political and economic concerns in the HKH is limited (Mukherji et al. 2018), and much of the discourse is driven by predetermined positions and not adequately informed by science or evidence (Singh and Thadani 2015). Completely ignored are the perspectives of the indigenous people who attribute sacredness to their landscapes and see hydropower dams as a further marginalizing act by hegemonic 
state- and private state-favored actors (Gergan 2017). While medium and large hydropower plants will be impacted by changes in the cryospheric components of the water cycle, this is unlikely to affect communities living in the vicinity of the cryosphere because they are constructed at elevations well below the cryospheric zone. However, there are numerous small and micro hydro plants located at higher elevations in the mountains, and there is hardly any literature that looks at the impact of these small structures on high mountain communities. One exception is McDowell et al. (2013), who documented the vulnerability of communities due to reduced winter production of hydroelectricity in the Khumbu region of Nepal. While acknowledging that hydropower is an important $\mathrm{CS}$, lack of evidence from the areas in the vicinity of the cryospheric zone means that we cannot assess the importance of this service for high mountain communities.

\section{Regulation services}

Regulation services impact at different temporal and spatial scales. Glaciers, and especially snow cover, regulate the climate due to the high albedo, i.e., they reflect most of the incoming solar radiation back to the atmosphere. And in addition to global climate regulation, they have a local cooling effect. Permafrost acts as a carbon sink or source, which alters atmospheric greenhouse gas emissions. The deep carbon pool in permafrost regions is an important component of the global terrestrial carbon cycle and has great importance, especially if thawing of permafrost continues as predicted, leading to increased emissions from both deep permafrost and surface soils to the atmosphere (Mu et al. 2018).

Rangelands are important as livestock grazing is one of the most important livelihood activities in high mountain areas, and the cryosphere plays an important role in maintaining the health of rangelands. A study in Mustang, Nepal, linked the degradation of pastures to declining snow accumulation, which leads to changes in the water-holding properties of soil (Paudel and Andersen 2010). In Qaidam Basin in the north of the Tibetan Plateau, degradation of permafrost along with an increase in precipitation has led to increased infiltration of precipitation and ice and snowmelt and a marked increase in groundwater storage. This is likely to impact not only the local environment but also global water storage and sea level changes (Jiao et al. 2015). Another study from the same region documented reduced winter runoff in the permafrost region as a result of large increases in surface ground temperature between 1979 and 2006 that led to permafrost degradation (Gao et al. 2016). Finally, another study from the Indian Himalaya shows a marked increase in peat deposition as a result of accelerated melting of snow and ice (Rühland et al. 2006). None of these studies looked at the human impacts of these changes.

\section{Societal and cultural services}

Somewhat less discussed, but very important, are the societal and cultural services provided by the cryosphere. Here, we document two major services for which case studies were available.

\section{Sacredness of landscapes}

The Himalaya has been represented as the "... abode of the gods and a sacred intermediary space connecting heaven and earth" (Howard 2016, p. 4). In much of Tibet and the TransHimalaya, like Ladakh, Manang, and Mustang, monastic Lamaism emerged as a higher-order organization within a cold-arid landscape which was originally inhabited by herdsmen and peasants (Pieper 1977, p. 41) and led to the creation of rules and regulations that govern many aspects of civic and religious life in the region to this day (Hovden 2013). Cryospheric features like snow, glaciers, and glacier lakes are often endowed with sacredness and meaning, and these belief systems exert influence on the way local communities perceive and interact with their surroundings. For example, the Buddhists of Bhutan and Nepal recognize various features of their immediate landscapes, such as snow peaks, rivers, and wildlife, as sacred, and this in turn determines land use practices, even though globalization has been weakening such links (Allison 2015). Similarly, older people in Ladakh see glacier lakes as sacred places (Ikeda et al. 2016). Devotees of Ganga blame the melting of the Gangotri-Gomukh glacier - the source of the holy river Ganga - on the increasingly unscrupulous behavior of humans (Drew 2013). Similar beliefs in the sacredness of mountains are held among many other communities, from Pamir in the west (Butz 1996) to Sikkim (Jain et al. 2004) and Arunachal Pradesh in the east (Samal et al. 2012). Gergan (2017), using ethnographic fieldwork, has documented how anti-dam protests in Sikkim are intricately related to beliefs about the sanctity of these landscapes.

\section{Tourism}

The scenic beauty of the HKH and the sacredness ascribed to the landscape make the region a highly valued tourist destination - both for leisure tourism and pilgrimage. Here, we refer to secular and sacred tourism as one entity, although there are conceptual differences between the two (Singh 2005). Tourism is on the rise in the vicinity of the cryospheric zone where features of the cryosphere, such as glaciers, wetlands, and scenic mountains, are major tourist attractions. In the Qinghai-Tibetan Plateau (QTP) in China, tourism contributes almost $30 \%$ of the region's GDP, and the region has seen a phenomenal rise in the number of tourists after the opening of the Qinghai-Tibetan Railway in 2006. Wang et al. (2017a) 
show that climate change would have varied impacts on tourism in the QTP — some positive, such as warmer winters and more glacier lakes, and some negative, such as disappearance of glaciers and drying up of lakes. The importance of glaciers in sustaining tourism and the negative effects, including the appeal of the "last chance" tourism, have been well documented in the case of Baishui Glacier No. 1 in the Yulong Snow Mountains (Wang et al. 2010). Another study by Yuan and He (2006) from the same area predicted a decline of $40 \%$ in domestic tourism in the absence of glaciers in the Yulong mountains, leading to an economic loss of 104-228 million USD (100 yuan $=15$ USD approx.). A similar narrative of rising temperatures, reduced snow cover, and possible threats to tourism also emerges from Indian Kashmir (Dar et al. 2014). In the Everest region in Nepal, tourism has seen a boost after the end of the Maoist insurgency in the late 1990s, and now almost 30,000 tourists, mostly trekkers and climbers, visit this region annually (McDowell et al. 2013). Here, the area under forests and shrubland has declined due to both the increased demand for timber for building lodges and heating tourist facilities and an increase in the male crossbreed cattle used as pack animals that tend to graze more intensively than local breeds. There have been changes in rainfall regimes and ice melt, and as a result, lodge owners see an imminent threat to their livelihoods due to water scarcity (Garrard et al. 2016). In other places in Nepal, the rise of tourism in remote mountain areas has led to a decline in transhumance (Aryal et al. 2018). In Bhutan, tourism contributes $15 \%$ of GDP and most of the country's foreign reserves, and there is a perceived threat among high mountain communities, who depend on activities like provision of lodgings and porter services, that their business may be affected due to rising temperatures, retreat of glaciers, and threats of extreme weather events (Hoy et al. 2016). In the Karakoram, moving away from agriculture and into tourism is seen as an adaptation strategy, but there have been no further studies aimed at understanding the impacts of these strategies (Kreutzmann 2012).

\section{Habitat services}

The HKH region has 13 of the world's 825 ecoregions (Shrestha et al. 2012). The cryosphere provides habitat for a number of microorganisms, plants, and animals, including "umbrella" species like the snow leopard (Lambeck 1997). As a result of the iconic status of the snow leopard, there are a number of papers that look at its current status and habitat conditions (Nyhus et al. 2016). Climate change, especially the upward shift of the snowline, has negatively affected snow leopard habitats (Forrest et al. 2012; Li et al. 2016), and suitable habitat areas are likely to be reduced in Bhutan, Nepal, India, and Myanmar by 2080 (Farrington and Li 2016). Bhatia et al. (2017) and Suryawanshi et al. (2013) used perception- based surveys in the Spiti Valley in Trans-Himalayan India to understand the issue of livestock predation by snow leopards and found that decisions about stocking of large-bodied animals like yaks and horses were determined by the perception of threat of predation by snow leopards and that the actual presence of snow leopards was determined by the amount of snowfall in the preceding years. Studies in Ladakh by Bhatia et al. (2017) show that local people's perception about large carnivores in the snow-packed regions depended on their degree of "religiosity." Another case study from the Chamoli district in India's Uttarakhand state unravels the divergence in the discourse among different stakeholders (Mathur 2015). Here, the state narrative invokes climate change, especially, reduced winter snowfall, as the main driver for increasing trends in human-animal conflict (both with leopards and bears) and the disappearance of musk deer, while local narratives speak of a state which is indifferent, corrupt, and in cahoots with poachers and private companies - and in the process is destroying the ecosystem of these endangered species. On the Tibetan Plateau, interviews with yak herders and local officials revealed large herd deaths in February and March in some years due to heavy snowfall leading to starvation in weaker animals - that are weakened due to higher temperatures during the rest of the year (Haynes et al. 2014).

Most studies on plant biodiversity show an overall shift in vegetation towards higher elevations due to a rise in temperature, leading to phenological changes such as lengthening of the overall growing season (Shrestha et al. 2012), and in some cases, for example, in the Sikkim Himalaya and Tibetan Plateau, an increased richness of species in the upper alpine zone (Telwala et al. 2013) due to changes in the snow regime (Chen et al. 2018; Wang et al. 2017b). A comprehensive study by Yang et al. (2018) on the Tibetan Plateau showed that climate warming increased aboveground net primary production (ANPP) at locations where permafrost was present but reduced ANPP at non-permafrost locations - thereby showing the importance of water supply services from permafrost in a cold-arid setting. Finally, a few studies looked at impacts of climate and local land use on microorganisms and found that arbuscular mycorrhizal (AM) fungal communities were not susceptible to short-term climate change or changes in grazing practices (Jiang et al. 2018). Another study found that the diversity of bacterial communities had gone down over time in Tianshan Glacier No. 1 in Tibet and that high bacterial diversity was associated with episodes of dust accumulation (Zhang et al. 2012). Again, none of the case studies documents how the habitat changes affect local communities or how local communities adapt to these changes, with the exception of Ingty (2017), which describes the use of traditional environmental knowledge to cope with some of the habitatrelated changes. 


\section{Disservices: cryosphere-related disasters}

Since mountain communities are often located in immediate proximity to the cryosphere, they not only benefit from it but also are exposed to several types of cryosphere-related risks causing potential damage or danger to their lives, livelihoods, and cultural heritage. These are called cryosphere disservices or, using the latest terminology, negative contributions of the cryosphere to people.

The vast majority of the case studies on cryosphere disservices are on glacial lake outburst floods (GLOFs), indicating their importance as a cause of great socioeconomic losses in the HKH (Iturrizaga 2005; Shijin and Shitai 2015) and in some instances far downstream (Allen et al. 2016). Bhutan and Nepal have recently been recognized as the two countries facing the greatest economic consequences from GLOFs worldwide (Carrivick and Tweed 2016), including threats to the unique cultural heritage (Kropáček et al. 2015; Sherry et al. 2018). Many studies also assess the socioeconomic losses emanating from past and potential future GLOF events in these countries (Cuellar and McKinney 2017; Gurung et al. 2017; Khanal et al. 2015).

Glacier and snowmelt often provide supply services by sustaining lean river discharge through the dry season. However, high glacier and snowmelt rates coinciding with torrential rainfall during the monsoon season can contribute to devastating floods, as in the Swat valley in Pakistan (Rahman and Khan 2011). On the other hand, decreased melt can lead to so-called snowmelt and glacier melt droughts (Van Loon et al. 2015). However, not all mountain communities depend on meltwater, and those that are not may not be critically affected by glacier change.

Surge-type glaciers, common in the Karakoram region (Ding et al. 2017), and other unstable glaciers, such as the two glaciers that collapsed in a remote region of the western Tibetan Plateau in July and September 2016 (Tian et al. 2017), pose a huge risk to communities located in their proximity. Recent work shows that the twin glacier collapses in Tibet were a result of climate- and weather-driven external forcing, coupled with the particular morphology of the glaciers themselves (Kääb et al. 2018). Debris flows, mudflows, and landslides are also more common in surge-type glaciers in the Karakoram (Iturrizaga 1997; McDonald 1989) and Tibet (Zhang and Shen 2011).

Extreme weather can bring cyclonic storms and anomalous snowfall over a very short period leading to unstable snow cover and a high risk of snow avalanches during and after the storms. Frequent snow storms pose a risk for animal husbandry in the QTP where snow disasters occur on an almost annual basis (Wang et al. 2016; Wei et al. 2017), also causing severe damage to infrastructure, including electricity transmission lines (Yeh et al. 2014). These kinds of severe snowstorm, which lead to large-scale loss of livestock, are projected to increase in intensity and frequency with climate change and expose the Tibetan herder communities to increasing risks (Wang et al. 2016; Yeh et al. 2014). Cyclone Hudhud in October 2015 caused a disaster that killed more than 50 people within 2 days in the Annapurna and Manaslu regions in Nepal as a result of sudden snowfall and avalanches (Sherpa et al. 2017). Anomalous winter snow accumulation also amplified the earthquake-induced disaster that killed more than 350 people and destroyed the entire village of Langtang in Nepal in 2015 (Fujita et al. 2017).

The case studies on cryosphere disservices and related socioeconomic vulnerability assessments and risk management strategies focus mainly on short-term events (Cuellar and McKinney 2017; Khanal et al. 2015; Wang and Zhou 2017). Cryosphere disservices, however, are often part of complex cascading disasters (Pescaroli and Alexander 2015), and they impact communities at different temporal and spatial scales. Besides cataclysmic events with a direct link to the cryosphere and instantaneous impact, such as GLOFs, snow storms, and avalanches, there are potential long-term risks due to the changing hydrological cycle and thawing permafrost that may have unpredictable impacts on mountain communities (Huggel et al. 2012). Rockfalls and landslides from thawing permafrost and glacier instability have been linked to cryospheric change. Many communities have developed their own adaptation and coping strategies for frequently occurring hazards when there are no or very limited resources for mitigation (Kreutzmann 2012; McDonald 1989; Yeh et al. 2014). However, specific forms of cryosphere disservices might either appear in new locations, where they have not previously been observed, or disappear due to further changes in the cryosphere.

There is a clear need to improve our understanding of the impacts of the long-term, cascading disservices by incorporating scientific knowledge into existing local knowledge (Ikeda et al. 2016) and further to explore the socio-cultural, health, and well-being dimensions and adaptation strategies of mountain communities at all scales. For instance, a study from a community living downstream of Tsho Rolpa, a potentially dangerous glacier lake in Nepal, shows that the community's sense of identity and subjective notion of well-being is closely linked with the landscape, and the threat of GLOFs manifests in a myriad different way (Sherry et al. 2018). There is still little understanding of these or of the interplay between cryosphere disservices and the other stresses, over which the mountain communities have little or no control. Faltering subsistence economies, migrant labor or forced displacement, and rapid urbanization heighten the risks from natural hazards by concentrating and increasing the vulnerability of certain segments of the population (Hewitt and Mehta 2012). Knowledge about these factors and processes is critical for understanding the forms of adaptation to hazards and for developing improved disaster risk reduction strategies (Diemberg et al. 2015). 


\section{Examining cryosphere services through a political ecology lens}

To sum up, our systematic qualitative review shows that the cryosphere provides a range of goods and services for communities living in the high mountain areas of the HKH. There is geographical disparity in the documentation of case studies, with some parts of the HKH being overrepresented (e.g., India and Nepal) and disservices being overwhelmingly documented from the Karakoram and Qinghai-Tibetan Plateau. Similarly, material services, like provisioning for irrigation and agriculture, are better documented than non-material services, like the spirituality of landscapes and support of identity and culture. Again, some of the services and contributions are documented with an interdisciplinary lens-for example, much of the literature on irrigation talks about the physical basis and human organization of irrigation, while much of the literature on disasters focuses on the physical processes and, at most, loss and damage assessments that focus on short-term impacts. Many of the case studies on irrigation investigate the interplay among cryosphere dynamics, glaciofluvial runoff, meltwater availability and distribution mechanisms, socioeconomic settings, external development interventions, and land use change (Nüsser 2017; Nüsser and Schmidt 2017; Parveen et al. 2015). These historically informed studies reveal singularly unique adaptation strategies to cope with water scarcity and risks associated with GLOFs. As cryospheric changes are characterized not only by spatial and temporal aspects but also by different symbolic, cultural, and political dimensions, the term cryoscape was proposed, to cover the whole set of implications (Nüsser 2017). Again, without explicitly stating it, many of the irrigation services papers have leaned towards a hydrosocial perspective by giving agency to mountain communities, who have actively shaped their responses to cryospheric changes. In contrast, most of the case studies on disasters fail to account for factors beyond the physical phenomena of landslides or glacier lake outburst that differentially affect different categories of people living in the vicinity of the cryosphere. For instance, Hewitt and Mehta (2012) underscore the importance of gender relations, local cultivation norms, and interactions of mountain communities with the outside monetized economy in determining an individual household's vulnerability and response to disasters. They also highlight the unforeseen scope and rapidity of changes resulting from forces like economic globalization and geopolitical strategies such as opening up of remote areas for trade, over which the communities have little or no control. However, most of the case studies miss out these factors and tend to present mountain communities in ways that are one-dimensional and reductionist.

Finally, our review shows that there is very little literature on impacts of cryospheric changes on various aspects of human societies that goes beyond perception studies and delves into oral history and traditions (Cruikshank 2001), on power and gender relationships (Halvorson 2002) and one that uses "pluralistic epistemologies" (Nightingale 2015) and historical perspectives (Kreutzmann 1993) to decode how various aspects of identity, such as wealth, caste, class, ethnicity, and gender, intersect to impact different sections of the mountain society differently. This lack of understanding of intersectionality is important as it has a direct bearing on the adaptation capabilities of high mountain communities, where it is apparent that many are indeed struggling to adapt to different climate and non-climatic changes (McDowell et al. 2014). Several studies from the HKH have highlighted the hegemonic role of state actors (Gergan 2017) which marginalizes the views of indigenous and mountain people and the overly biophysical narratives and solutions that further undermine the complexity of environmental issues in the region (Satyal et al. 2017). However, these views are not integrated in most of the case studies.

\section{Conclusion}

As a way forward, we propose that future research in the area of cryosphere-human society interaction adopts a pragmatic approach of fostering interdisciplinary collaboration in which differences in disciplines and their underpinnings are explicitly understood and unpacked and that tools from different disciplines are triangulated in order to understand findings that may or may not be contradictory. Data gaps in the HKH are already well recognized, and we reiterate the need for longterm collaboration across disciplines and sectors to systematically fill these gaps (Singh and Thadani 2015). In doing so and given the gaps in our current understanding of the impact of cryospheric changes on human societies, we propose that human impacts be understood through pluralistic and critical epistemologies using a lens of power, politics, and intersectionality to help identify those communities or subsections of communities who get left behind when severe changes happen in the cryosphere. This is important because, we contend, those who face exclusion in the mountains are among the most marginalized people in the world.

Acknowledgements The authors would also like to thank the following ICIMOD colleagues: Mr. Devesh Belbase, Ms. Nisha Wagle, Mr. Anil Jha, and Ms. Sarita Joshi for help with bibliographic searches and referencing; Mr. Gauri Dangol, Mr. Sudip Maharjan, and Ms. Chimi Seldon for their assistance in preparing maps and figures; and Ms. Beatrice Murray for language editing.

Funding information This work was supported by ICIMOD's Cryosphere Initiative, funded by Norway and by ICIMOD core funds contributed by the governments of Afghanistan, Australia, Austria, Bangladesh, Bhutan, China, India, Myanmar, Nepal, Norway, Pakistan, Sweden, and Switzerland. 


\section{Compliance with ethical standards}

Disclaimer The views and interpretations in this publication are those of the authors and are not necessarily attributable to their organizations.

Open Access This article is distributed under the terms of the Creative Commons Attribution 4.0 International License (http:// creativecommons.org/licenses/by/4.0/), which permits unrestricted use, distribution, and reproduction in any medium, provided you give appropriate credit to the original author(s) and the source, provide a link to the Creative Commons license, and indicate if changes were made.

\section{References}

Aase TH, Chaudhary RP, Vetaas OR (2010) Farming flexibility and food security under climatic uncertainty: Manang, Nepal Himalaya. Area 42(2):228-238. https://doi.org/10.1111/j.1475-4762.2009.00911.x

Allan NJR (1985) Human geo-ecological interactions in Kuh Daman, a South Asian mountain valley. Appl Geogr 5(1):13-27. https://doi. org/10.1016/0143-6228(85)90003-7

Allen SK, Linsbauer A, Randhawa SS, Huggel C, Rana R, Kumari A (2016) Glacial lake outburst flood risk in Himachal Pradesh, India: an integrative and anticipatory approach considering current and future threats. Nat Hazards 84:1741-1763. https://doi.org/10.1007/ 211069-016-2511-x

Allison EA (2015) The spiritual significance of glaciers in an age of climate change. Wiley Interdiscip Rev Clim Chang 6(5):493-508. https://doi.org/10.1002/wcc.354

Aryal S, Cockfield G, Maraseni TN (2018) Globalisation and traditional social-ecological systems: understanding impacts of tourism and labour migration to the transhumance systems in the Himalayas. Environmental Development 25:73-84. https://doi.org/10.1016/j. envdev.2017.09.001

Basannagari B, Kala CP (2013) Climate change and apple farming in Indian Himalayas: a study of local perceptions and responses. PLoS One 8(10):e77976. https://doi.org/10.1371/journal.pone. 0077976

Becken S, Lama AK, Espiner S (2013) The cultural context of climate change impacts: perceptions among community members in the Annapurna Conservation Area, Nepal. Environmental Development 8(1):22-37. https://doi.org/10.1016/j.envdev.2013. 05.007

Bhatia S, Redpath SM, Suryawanshi K, Mishra C (2017) The relationship between religion and attitudes toward large carnivores in northern India. Hum Dimens Wildl 22(1):30-42. https://doi.org/10.1080/ 10871209.2016.1220034

Blaikie PM, Muldavin JSS (2004) Upstream, downstream, China, India: the politics of environment in the Himalaya Region. Ann Assoc Am Geogr 94(3):520-548. https://doi.org/10.1111/j.1467-8306.2004. 00412.x

Bodansky D (2016) The Paris climate change agreement: a new hope? American Journal of International Law 110(2):288-319. https://doi. org/10.5305/amerjintelaw.110.2.0288

Boelens R (2014) Cultural politics and the hydrosocial cycle: water, power and identity in the Andean highlands. Geoforum 57:234-247. https://doi.org/10.1016/j.geoforum.2013.02.008

Bolch T, Kulkarni A, Kääb A, Huggel C, Paul F, Cogley JG, Frey H, Kargel JS, Fujita K, Scheel M, Bajracharya S, Stoffel M (2012) The state and fate of Himalayan glaciers. Science 336(6079):310-314. https://doi.org/10.1126/science.1215828

Brun F, Berthier E, Wagnon P, Kääb A, Treichler D (2017) A spatially resolved estimate of High Mountain Asia glacier mass balances from 2000 to 2016. Nat Geosci 10:668-673. https://doi.org/10. 1038/ngeo2999

Brush SB (1976) Introduction to cultural adaptations to mountain ecosystems. Hum Ecol 4(2):125-133

Butz D (1989) The agricultural use of melt water in Hopar settlement, Pakistan. Ann Glaciol 13:35-39. https://doi.org/10.3189/ S0260305500007606

Butz D (1996) Sustaining indigenous communities: symbolic and instrumental dimensions of pastoral resource use in Shimshal, northern Pakistan. Can Geogr 40(1):36-53. https://doi.org/10.1111/j.15410064.1996.tb00431.x

Cannon F, Carvalho LMV, Jones C, Bookhagen B (2014) Multi-annual variations in winter westerly disturbance activity affecting the Himalaya. Clim Dyn 44(1-2):441-455. https://doi.org/10.1007/ s00382-014-2248-8

Carrivick JL, Tweed FS (2016) A global assessment of the societal impacts of glaciers outburst floods. Glob Planet Chang 144:1-16. https://doi.org/10.1016/j.gloplacha.2016.07.001

Chalaune P (2009) Water, wealth, and power: a case study from Upper Mustang of Nepal. Occas Pap Sociol Anthropol 11:104-125. https:// doi.org/10.3126/opsa.v11i0.3033

Chaudhary S, McGregor A (2018) A critical analysis of global ecosystem services ( Paristhitiki sewa) discourse in Nepal. Land Use Policy 75: 364-374. https://doi.org/10.1016/j.landusepol.2018.03.024

Chen R, Wang G, Yang Y, Liu J, Han C, Song Y, Liu X, Kang E (2018) Effects of cryospheric change on alpine hydrology: combining a model with observations in the upper reaches of the Hei River, China. Journal of Geophysical Research: Atmospheres 123(7): 3414-3442. https://doi.org/10.1002/2017JD027876

Cruikshank J (2001) Glaciers and climate change : perspectives from oral tradition. Arctic 54(4):377-393. https://doi.org/10.14430/arctic795

Cuellar AD, McKinney DC (2017) Decision-making methodology for risk management applied to Imja Lake in Nepal. Water 9(8):14 16. https://doi.org/10.3390/w9080591

Dar RA, Rashid I, Romshoo SA, Marazi A (2014) Sustainability of winter tourism in a changing climate over Kashmir Himalaya. Environ Monit Assess 186(4):2549-2562. https://doi.org/10.1007/s10661013-3559-7

De Xiao C, Wang SJ, Qin DH (2015) A preliminary study of cryosphere service function and value evaluation. Adv Clim Chang Res 6(3-4): 181-187. https://doi.org/10.1016/j.accre.2015.11.004

Díaz S, Pascual U, Stenseke M, Martín-López B, Watson RT, Molnár Z, Hill R, Chan KMA, Baste IA, Brauman KA, Polasky S, Church A, Lonsdale Larigauderie A, Leadley PW, van Oudenhover APE, van der Plaat F, Schröter M, Lavorel S, Thomas YA, Bukvareva E, Davies K, Demissew S, Erpul G, Failler P, Guerra CA, Hewitt CL, Keune H, Lindley S, Shirayama Y (2018) Assessing nature's contributions to people. Science 359(6373):270-272. https://doi.org/10. 1126/science.aap8826

Diemberg H, Hovden A, Yeh ET (2015) The honour of the snowmountains is the snow, Tibetan livelihoods in a changing climate. In: Huggel C, Carey M, Clague JJ, Kääb A (eds) The high-mountain cryosphere: environmental changes and human risks. Cambridge University Press, Cambridge, pp 249-271

Ding M, Huai B, Sun W, Wang Y, Zhang D, Guo X, Zhang T (2017) Surge-type glaciers in Karakoram Mountain and possible catastrophes alongside a portion of the Karakoram. Nat Hazards 90(2): 1017-1020. https://doi.org/10.1007/s11069-017-3063-4

Drew G (2013) A retreating goddess? Conflicting perceptions of ecological change near the Gangotri-Gaumukh glacier. Journal for the Study of Religion, Nature and Culture 6(3):344-362. https://doi. org/10.4324/9780203082799

Fabinyi M, Evans L, Foale SJ (2014) Social-ecological systems, social diversity, and power: insights from anthropology and political ecology. Ecol Soc 19(4). https://doi.org/10.5751/ES-07029-190428 
Farrington JD, Li J (2016) Climate change impacts on snow leopard range. In: Nyhus PJ, McCarthy T, Mallon D (eds) Snow leopards: biodiversity of the world: conservation from genes to landscapes. Elsevier Academic Press, London, pp 85-95. https://doi.org/10. 1016/B978-0-12-802213-9.00008-0

Ford JD, Bolton K, Shirley J, Pearce T, Tremblay M, Westlake M (2012) Mapping human dimensions of climate change research in the Canadian Arctic. Ambio 41(8):808-822. https://doi.org/10.1007/ s13280-012-0336-8

Forrest JL, Wikramanayake E, Shrestha R, Areendran G, Gyeltshen K, Maheshwari A, Mazumdar S, Naidoo R, Thapa GJ, Thapa K (2012) Conservation and climate change: assessing the vulnerability of snow leopard habitat to treeline shift in the Himalaya. Biol Conserv 150(1):129-135. https://doi.org/10.1016/j.biocon.2012. 03.001

Fort M (2014) Natural hazards versus climate change and their potential impacts in the dry, northern Himalayas: focus on the upper Kali Gandaki (Mustang District, Nepal). Environmental Earth Sciences 73(2):801-814. https://doi.org/10.1007/s12665-014-3087-y

Fujita K, Inoue H, Izumi T, Yamaguchi S, Sadakane A, Sunako S, Nishimura K, Immerzeel WW, Shea JM, Kayashta RB, Sawagaki T, Breashears DF, Yagi H, Sakai A (2017) Anomalous winter snow amplified earthquake induced disaster of the 2015 Langtang avalanche in Nepal. Nat Hazards Earth Syst Sci 17:749-764. https:// doi.org/10.5194/nhess-17-749-2017

Gao T, Zhang T, Cao L, Kang S, Sillanpää M (2016) Reduced winter runoff in a mountainous permafrost region in the northern Tibetan Plateau. Cold Reg Sci Technol 126:36-43. https://doi.org/10.1016/j. coldregions.2016.03.007

Garrard R, Kohler T, Wiesmann U, Price MF, Byers AC, Sherpa AR (2012) Depicting community perspectives: repeat photography and participatory research as tools for assessing environmental services in Sagarmatha National Park, Nepal. Eco Mont 4(2):21-31. https:// doi.org/10.1553/eco.mont-4-2s21

Garrard R, Kohler T, Price MF, Byers AC, Sherpa AR, Maharjan GR (2016) Land use and land cover change in Sagarmatha National Park, a world heritage site in the Himalayas of Eastern Nepal. Mt Res Dev 36(3):299-310. https://doi.org/10.1659/MRD-JOURNALD-15-00005.1

Gergan MD (2017) Living with earthquakes and angry deities at the Himalayan borderlands. Annals of the American Association of Geographers 107(2):490-498. https://doi.org/10.1080/24694452. 2016.1209103

Gioli G, Khan T, Scheffran J (2014) Climatic and environmental change in the Karakoram: making sense of community perceptions and adaptation strategies. Reg Environ Chang 14(3):1151-1162. https://doi.org/10.1007/s10113-013-0550-3

Goldstein MC, Messerschmidt DA (1980) The significance of latitudinality in Himalayan mountain ecosystems. Hum Ecol 8(2): 117-134. https://doi.org/10.1007/BF01531438

Gruber S, Fleiner R, Guegan E, Panday P, Schmid MO, Stumm D, Wester P, Zhang Y, Zhao L (2017) Review article: inferring permafrost and permafrost thaw in the mountains of the Hindu Kush Himalaya region. Cryosphere 11(1):81-99. https://doi.org/10.5194/tc-11-812017

Guo D, Wang H, Li D (2012) A projection of permafrost degradation on the Tibetan Plateau during the 21st century. Journal of Geophysical Research: Atmospheres 117(D05106). https://doi.org/10.1029/ 2011JD016545

Guo L, Xie Y, Yu Q, You Y, Wang X, Li X (2016) Displacements of tower foundations in permafrost regions along the Qinghai-Tibet power transmission line. Cold Reg Sci Technol 121:187-195. https://doi. org/10.1016/j.coldregions.2015.07.012

Gurung DR, Khanal NR, Bajracharya SR, Tsering K, Joshi S, Tshering P, Chhetri LK, Lotay Y, Penjor T (2017) Lemthang Tsho glacial lake outburst flood (GLOF) in Bhutan: cause and impact.
Geoenvironmental Disasters 4:17. https://doi.org/10.1186/s40677017-0080-2

Halvorson SJ (2002) Environmental health risks and gender in the Karakoram-Himalaya, northern Parkistan. Geogr Rev 92(2):257281. https://doi.org/10.2307/4140973

Haynes MA, Kung K-JS, Brandt JS, Yongping Y, Waller DM (2014) Accelerated climate change and its potential impact on yak herding livelihoods in the eastern Tibetan plateau. Clim Chang 123(2):147160. https://doi.org/10.1007/s10584-013-1043-6

Hewitt K, Mehta M (2012) Rethinking risk and disasters in mountain areas. Revue de Géographie Alpine 100-1:13. https://doi.org/10. 4000/rga. 1653

Hill J (2014) Farmer-managed irrigation systems in Baltistan and Kargil. Ladakh Studies 31:4-23

Hill JKW (2017) Supporting farmer-managed irrigation systems in the Shigar valley, Karakorum: role of the government and Aga Khan Rural Support Programme. J Mt Sci 14(10):2064-2081. https://doi. org/10.1007/s11629-017-4496-7

Hoegh-Guldberg O, Jacob D, Taylor M, Bindi M, Brown S, Camilloni I, Diedhiou A Djalante R, Ebi K, Engelbrecht F, Guiot J, Hijioka Y, Mehrotra S, Payne A, Seneviratne SI, Thomas A, Warren R, Zhou $\mathrm{G}$ (2018) Impacts of $1.5^{\circ} \mathrm{C}$ global warming on natural and human systems. In: Global warming of $1.5^{\circ} \mathrm{C}$. An IPCC Special Report on the impacts of global warming of $1.5^{\circ} \mathrm{C}$ above pre-industrial levels and related global greenhouse gas emission pathways, in the context of strengthening the global response to the threat of climate change, sustainable development, and efforts to eradicate poverty [MassonDelmotte V, Zhai P, Pörtner HO, Roberts D, Skea J, Shukla PR, Pirani A, Moufouma-Okia W, Péan C, Pidcock R, Connors S, Matthews JBR, Chen Y, Zhou X, Gomis MI, Lonnoy E, Maycock T, Tignor M, Waterfield T (eds.)]. In Press.

Hovden A (2013) Who were the sponsors? Reflections on recruitment and ritual economy in three Himalayan village monasteries. In: Ramble C, Schwieger P, Travers A (eds) Tibetans who escaped the historian's net: studies in the social history of Tibetan societies. Vajra Books, Kathmandu, pp 209-230

Howard CA (2016) Walking with the gods: the Himalayas as(dis)enchanted landscape. In: Tejada JM, Tatar B (eds) Transnational frontiers of Asia and Latin America since 1800, 1st edn. Routledge, London, p 274

Hoy A, Katel O, Thapa P, Dendup N, Matschullat J (2016) Climatic changes and their impact on socio-economic sectors in the Bhutan Himalayas: an implementation strategy. Reg Environ Chang 16(5): 1401-1415. https://doi.org/10.1007/s10113-015-0868-0

Huber A, Joshi D (2015) Hydropower, anti-politics, and the opening of new political spaces in the Eastern Himalayas. World Dev 76(289374):13-25. https://doi.org/10.1016/j.worlddev.2015.06.006

Huggel C, Clague JJ, Korup O (2012) Is climate change responsible for changing landslide activity in high mountains? Earth surgace processes and landforms 37:77-91. https://doi.org/10.1002/esp.2223

Huss M, Hock R (2018) Global-scale hydrological response to future glacier mass loss. Nat Clim Chang 8:135-140. https://doi.org/10. 1038/s41558-017-0049-x

Ikeda N, Narama C, Gyalson S (2016) Knowledge sharing for disaster risk reduction: insights from a glacier lake workshop in the Ladakh region, Indian Himalayas. Mt Res Dev 36(1):31-40. https://doi.org/ 10.1659/MRD-JOURNAL-D-15-00035.1

Immerzeel WW, van Beek LPH, Konz M, Shrestha AB, Bierkens MFP (2012) Hydrological response to climate change in a glacierized catchment in the Himalayas. Clim Chang 110(3-4):721-736. https://doi.org/10.1007/s10584-011-0143-4

Ingty T (2017) High mountain communities and climate change: adaptation, traditional ecological knowledge, and institutions. Clim Chang 145(1-2):41-55. https://doi.org/10.1007/s10584-017-2080-3

Iturrizaga L (1997) The valley of Shimshal - a geographical portrait of a remote high mountain settlement and its pastures with reference to 
environmental habitat conditions in the North-West Karakorum (Pakistan). GeoJournal 42(2-3):303-328. https://doi.org/10. 1023/A:1006869406576

Iturrizaga L (2005) New observations on present and prehistorical glacier-dammed lakes in the Shimshal Valley (Karakoram Mountains). J Asian Earth Sci 25(4):545-555. https://doi.org/10. 1016/j.jseaes.2004.04.011

Ives J (2004) Himalayan perceptions: environmental change and the wellbeing of mountain peoples. Himal J Sci 2(3):17-19. https://doi.org/ 10.3126/hjs.v2i3.224

Jain A, Singh HB, Rai SC, Sharma E (2004) Folklores of sacred Khecheopalri Lake in the Sikkim Himalaya of India: a plea for conservation. Asian Folklore Studies 63(2):291-302 https://www. jstor.org/stable/30030339. Accessed 15 Dec 2017

Jiang S, Pan J, Shi G, Dorji T, Hopping KA, Klein JA, Liu Y, Feng H (2018) Identification of root-colonizing AM fungal communities and their responses to short-term climate change and grazing on Tibetan plateau. Symbiosis 74(3):159-166. https://doi.org/10. 1007/s13199-017-0497-0

Jiao JJ, Zhang X, Liu Y, Kuang X (2015) Increased water storage in the Qaidam Basin, the North Tibet Plateau from GRACE gravity data. PLoS One 10(10):1-12. https://doi.org/10.1371/journal.pone. 0141442

Kääb A, Treichler D, Nuth C, Berthier E (2015) Brief communication: contending estimates of 2003-2008 glacier mass balance over the Pamir-Karakoram-Himalaya. Cryosphere 9(2):557-564. https://doi. org/10.5194/tc-9-557-2015

Kääb A, Leinss S, Gilbert A, Bühler Y, Gascoin S, Evans SG, Bartelt P, Berthier E, Brun F, Chao WA, Farinotti D, Gimbert F, Guo W, Huggel C, Kargel JS, Leonard GJ, Tian L, Treichler D, Yao T (2018) Massive collapse of two glaciers in western Tibet in 2016 after surge-like instability. Nat Geosci 11(2):114-120. https://doi. org/10.1038/s41561-017-0039-7

Kaser G, Großhauser M, Marzeion B (2010) Contribution potential of glaciers to water availability in different climate regimes. Proceedings of the National Academy of Sciences of the United States of America 107(47):20223-20227 www.pnas.org/cgi/doi/ 10.1073/pnas.1008162107. Accessed 15 Dec 2017

Kates RW (2002) Humboldt's dream, beyond disciplines, and sustainability science: contested identities in a restructuring academy. Annals of Association of American Geographers 92(1):75-86

Khanal NR, Hu JM, Mool P (2015) Glacial lake outburst flood risk in the Poiqu / Bhote Koshi / Sun Koshi River Basin in the Central Himalayas. 35(4):351-64. https://doi.org/10.1659/MRDJOURNAL-D-15-00009

Konchar KM, Staver B, Salick J, Chapagain A, Joshi L, Karki S, Lo S, Paudel A, Subedi P, Ghimire SK (2015) Adapting in the shadow of Annapurna: a climate tipping point. J Ethnobiol 35(3):449-471. https://doi.org/10.2993/0278-0771-35.3.449

Kraaijenbrink PDA, Bierkens MFP, Lutz AF, Immerzeel WW (2017) Impact of a global temperature rise of 1.5 degrees Celsius on Asia's glaciers. Nature 549(7671):257-260. https://doi.org/10. 1038/nature23878

Kreutzmann H (1993) Challenge and response in the Karakoram: socioeconomic transformation in Hunza, northern areas, Pakistan. Mt Res Dev 13(1):19-39. https://doi.org/10.1073/pnas.0703993104

Kreutzmann H (2012) After the flood: mobility as an adaptation strategy in high mountain oases. The case of Pasu in Gojal, Hunza valley, Karakoram. Die Erde 143(1-2):49-73

Kropáček J, Neckel N, Tyrna B, Holzer N, Hovden A, Gourmelen N, Schneider C, Buchroithner M, Hochschild V (2015) Repeated glacial lake outburst flood threatening the oldest Buddhist monastery in North-Western Nepal. 15:2425-2437. doi:https://doi.org/10.5194/ nhess-15-2425-2015
Kull CA, de Sartre XA, Castro-Larrañaga M (2015) The political ecology of ecosystem services. Geoforum 61:122-134. https://doi.org/10. 1016/J.GEOFORUM.2015.03.004

Lambeck RJ (1997) Focal species: a multi-species umbrella for nature conservation. Conserv Biol 11(4):849-856. https://doi.org/10.1046/ j.1523-1739.1997.96319.x

Lamsal P, Kumar L, Atreya K (2017) Historical evidence of climatic variability and changes, and its effect on high-altitude regions: insights from Rara and Langtang, Nepal. Int J Sust Dev World 24(6): 471-484. https://doi.org/10.1080/13504509.2016.1198939

Le Masson V, Nair K (2015) Does climate modeling help with studying adaptation to environmental changes? The case of Ladakh, India. In: Armando L, Kelman I (eds) Climate change modeling for local adaptation in the Hindu Kush Himalayan region. Emerald Group Publishing Limited, UK, pp 75-94

Li J, McCarthy TM, Wang H, Weckworth BV, Schaller GB, Mishra C, Lu Z, Beissinger SR (2016) Climate refugia of snow leopards in High Asia. Biol Conserv 203:188-196. https://doi.org/10.1016/j.biocon. 2016.09.026

Linton J, Budds J (2014) The hydrosocial cycle: defining and mobilizing a relational-dialectical approach to water. Geoforum 57:170-180. https://doi.org/10.1016/j.geoforum.2013.10.008

Lutz AF, Immerzeel WW, Shrestha AB, Bierkens MFP (2014) Consistent increase in High Asia's runoff due to increasing glacier melt and precipitation. Nat Clim Chang 4(7):587-592. https://doi.org/10. 1038/nclimate2237

Lutz AF, Immerzeel WW, Kraaijenbrink PDA, Shrestha AB, Bierkens MFP (2016) Climate change impacts on the upper indus hydrology: sources, shifts and extremes. PLoS One 11(11):1-33. https://doi.org/ 10.1371/journal.pone.0165630

Lutz AF, Maat HW, Wijngaard RR, Biemans H, Syed A, Shrestha AB, Wester P, Immerzeel WW (2018) South Asian river basins in a $1.5^{\circ} \mathrm{C}$ warmer world. Regional Environmental Change. https://doi.org/10. 1007/s10113-018-1433-4

Mach KJ, Planton S, von Stechow C (2014) Annex II: Glossary. In: Pachauri RK, Meyer LA (eds) Climate change 2014: synthesis report. Contribution of working groups I, II and III to the fifth assessment report of the intergovernmental panel on climate change. Cambridge University Press, Geneva, pp 117-130

Manandhar S, Pandey VP, Kazama F (2012) Hydro-climatic trends and people's perceptions: case of Kali Gandaki River Basin, Nepal. Clim Res 54(2):167-179. https://doi.org/10.3354/cr01108

Mathur N (2015) "It's a conspiracy theory and climate change" of beastly encounters and cervine disappearances in Himlayan India. Journal of Ethnographic Theory 5(1):87-111. https://doi.org/10.14318/ hau5.1.005

McDonald KI (1989) Impacts of glacier-related landslides on the settlement at Hopar, Karakoram Himalaya. Ann Glaciol 13:185-188. https://doi.org/10.3189/S0260305500007826

McDowell G, Ford JD, Lehner B, Berrang-Ford L, Sherpa A (2013) Climate-related hydrological change and human vulnerability in remote mountain regions: a case study from Khumbu, Nepal. Reg Environ Chang 13(2):299-310. https://doi.org/10.1007/s10113012-0333-2

McDowell G, Stephenson E, Ford J (2014) Adaptation to climate change in glaciated mountain regions. Clim Chang 126(1-2):77-91. https:// doi.org/10.1007/s10584-014-1215-Z

Moors EJ, Stoffel M (2013) Changing monsoon patterns, snow and glacial melt, its impacts and adaptation options in northern India: synthesis. Sci Total Environ 468-469:S162-S167. https://doi.org/10. 1016/j.scitotenv.2013.11.058

Mu C, Li L, Wu X, Zhang F, Jia L, Zhao Q, Zhang T (2018) Greenhouse gas released from the deep permafrost in the northern QinghaiTibetan Plateau. Sci Rep 8(1):1-9. https://doi.org/10.1038/s41598$018-22530-3$ 
Mukherji A, Molden D, Nepal S, Rasul G, Wagnon P (2015) Himalayan waters at the crossroads: issues and challenges. International Journal of Water Resources Development 31(2):151-160. https://doi.org/10. 1080/07900627.2015.1040871

Mukherji, A., Scott, C., Molden, D., \& Maharjan, A. (2018). Megatrends in Hindu Kush Himalaya: climate change, urbanisation and migration and their implications for water, energy and food. In A. K. Biswas, C. Tortajada, \& P. Rohner (Eds.), Assessing global water megatrends (pp. 125-146). Springer. doi https://doi.org/10.1007/ 978-981-10-6695-5 8

Muldavin J (2008) The time and place for political ecology: an introduction to the articles honoring the life-work of Piers Blaikie. Geoforum 39(2):687-697. https://doi.org/10.1016/j.geoforum.2007.07.003

Nepal S, Flügel W-A, Shrestha AB (2014) Upstream-downstream linkages of hydrological processes in the Himalayan region. Ecol Process 3(1):19. https://doi.org/10.1186/s13717-014-0019-4

Nightingale AJ (2015) Adaptive scholarship and situated knowledges? Hybrid methodologies and plural epistemologies in climate change adaptation research. Area 48(1):41-47. https://doi.org/10.1111/area. 12195

Nüsser M (2017) Socio-hydrology: a new perspective on mountain waterscapes at the nexus of natural and social processes. Mt Res Dev 37(4):518-520. https://doi.org/10.1659/MRD-JOURNAL-D17-00101.1

Nüsser M, Baghel R (2016) Local knowledge and global concerns: artificial glaciers as a focus of environmental knowledge and development interventions. In: Meusberger P, Freytag T, Suarsana L (ed) Ethnic and cultural dimensions of knowledge (Vol. 8). Springer, pp 191-209. doi https://doi.org/10.1007/978-3-319-21900-4

Nüsser M, Clemens J (1996) Impacts on mixed mountain agriculture in the rupal valley, Nanga Parbat, northern Pakistan. Mountain Research and Development 16(2):117-133. https://doi.org/10. 2307/3674006

Nüsser M, Schmidt S (2017) Nanga Parbat revisited: evolution and dynamics of sociohydrological interactions in the Northwestern Himalaya. Annals of the American Association of Geographers 107(2):403-415. https://doi.org/10.1080/24694452.2016.1235495

Nüsser M, Schmidt S, Dame J (2012) Irrigation and development in the Upper Indus Basin: characteristics and recent changes of a sociohydrological system in Central Ladakh, India. Mt Res Dev 32(1): 51-61. https://doi.org/10.1659/MRD-JOURNAL-D-11-00091.1

Nüsser M, Dame J, Kraus B, Baghel R, Schmidt S (2018) Sociohydrology of "artificial glaciers" in Ladakh, India: assessing adaptive strategies in a changing cryosphere. Reg Environ Chang 1-11. doi https://doi.org/10.1007/s10113-018-1372-0

Nyhus PJ, McCarthy T, Mallon D (2016) Snow leopards: biodiversity of the world: conservation from genes to landscapes. Elsevier Academic Press, London. https://doi.org/10.1016/B978-0-12802213-9/00068-7

Palomo I (2017) Climate change impacts on ecosystem services in high mountain areas: a literature review. Mt Res Dev 37(2):179-187. https://doi.org/10.1659/MRD-JOURNAL-D-16-00110.1

Parveen S, Winiger M, Schmidt S, Nüsser M (2015) Irrigation in Upper Hunza: evolution of socio-hydrological interactions in the Karakoram, northern Pakistan. Erdkunde 69(1):69-85. https://doi. org/10.3112/erdkunde.2015.01.05

Paudel KP, Andersen P (2010) Assessing rangeland degradation using multi temporal satellite images and grazing pressure surface model in Upper Mustang, Trans Himalaya, Nepal. Remote Sens Environ 114(8):1845-1855. https://doi.org/10.1016/j.rse.2010.03.011

Pescaroli G, Alexander D (2015) A defination of cascading disasters and cascading effects: going beyond the "toppling dominos" metaphor. Planet @ risk 3(1), special issue on the $5^{\text {th }}$ IDRC Davos 2014

Pieper J (1977) The monastic settlements of the yellow church in Ladakhcentral places in a nomadic habitat. GeoJournal 1(5):41-54 https:// www.jstor.org/stable/41142038. Accessed 15 Dec 2017
Prem SC, Jagat KB (2013) Changing water regime and adaptation strategies in Upper Mustang Valley of Upper Kaligandaki Basin in Nepal. Sciences in Cold and Arid Regions 5(1):133. https://doi. org/10.3724/SP.J.1226.2013.00133

Qin D, Ding Y, Xiao C, Kang S, Ren J, Yang J, Zhang S (2017) Cryospheric science: research framework and disciplinary system. Geosciences 5:1-14. https://doi.org/10.1093/nsr/nwx108

Rahman A-u, Khan AN (2011) Analysis of flood causes and associated socio-economic damages in the Hindukush region. Nat Hazards 59: 1239-1260. https://doi.org/10.1007/s11069-011-9830-8

Rühland K, Phadtare NR, Pant RK, Sangode SJ, Smol JP (2006) Accelerated melting of Himalayan snow and ice triggers pronounced changes in a valley peatland from northern India. Geophys Res Lett 33(15):1-6. https://doi.org/10.1029/ 2006GL026704

Salick J, Yongping Y, Amend A (2005) Tibetan land use and change near Khawa Karpo, Eastern Himalayas. Econ Bot 59(4):312-325. https:// doi.org/10.1663/0013-0001(2005)059[0312:TLUACN]2.0.CO;2

Samal PK, Mazumdar K, Megejee D, Dollo M (2012) Conservation values of Monpas and Sherdukpens of Aurnachal Pradesh. In: Ramakrishnan PS, Saxena KG, Rao RS, Sharma G (eds) Cultural landscapes:the basis for linking biodiversity conservation with sustainable development. UNESCO, New Delhi, pp 83-103

Sanderson MR (2018) Everything flows...unevenly: social stratification in coupled socio-ecological systems. Curr Opin Environ Sustain 33: 51-57. https://doi.org/10.1016/j.cosust.2018.04.012

Satyal P, Shrestha K, Ojha H, Vira B, Adhikari J (2017) A new Himalayan crisis? Exploring transformative resilience pathways. Environmental Development 23:47-56. https://doi.org/10.1016/j. envdev.2017.02.010

Shaheen FA, Wani MH, Wani SA, Norphel C (2013) Climate change impact in cold arid desert of north-western Himalaya:community. In: Nautiyal S, Rao KS, Kaechele H, Raju KV, Schaldach R (eds) Knowledge systems of societies for adaptation and mitigation of impacts of climate change. Springer-Verlag, Berlin, pp 239-256. https://doi.org/10.1007/978-3-642-36143-2

Sherpa PY (2014) Climate change, perceptions, and social heterogeneity in Pharak, Mount Everest region of Nepal. Hum Organ 73(2):153161. https://doi.org/10.17730/humo.73.2.94q43152111733t6

Sherpa SF, Wagnon P, Brun F, Berthier E, Vincent C, Lejeune Y, Arnaud Y, Kayastha RB, Sinisalo A (2017) Contrasted surface mass balances of debris-free glaciers observed between the southern and the inner parts of the Everest region (2007-2015). J Glaciol 63: 637-651. https://doi.org/10.1017/jog.2017.30

Sherry J, Curtis A, Mendham E, Toman E (2018) Cultural landscapes at risk : exploring the meaning of place in a Sacred Valley of Nepal. Glob Environ Chang 52:190-200. https://doi.org/10.1016/j. gloenvcha.2018.07.007

Shijin W, Shitai J (2015) Evolution and outburst risk analysis of morainedammed lakes in the central Chinese Himalaya. J Earth Syst Sci 124(3):567-576. https://doi.org/10.1007/s12040-015-0559-8

Shrestha UB, Gautam S, Bawa KS (2012) Widespread climate change in the Himalayas and associated changes in local ecosystems. PLoS One 7(5):1-10. https://doi.org/10.1371/journal.pone.0036741

Shrestha F, Gao X, Khanal NR, Maharjan SB, Shrestha RB, Wu L, Mool PK, Bajracharya SR (2017) Decadal glacial lake changes in the Koshi basin, central Himalaya, from 1977 to 2010, derived from Landsat satellite images. J Mt Sci 14(10):1969-1984. https://doi. org/10.1007/s11629-016-4230-x

Siderius C, Biemans H, Wiltshire A, Rao S, Franssen WHP, Kumar P, Gosain AK, van Vliet MTH, Collins DN (2013) Snowmelt contributions to discharge of the Ganges. Sci Total Environ 468-469:S93S101. https://doi.org/10.1016/j.scitotenv.2013.05.084

Singh S (2005) Secular pilgrimages and sacred tourism in the Indian Himalayas. GeoJournal 64(3):215-223. https://doi.org/10.1007/ s10708-005-5649-8 
Singh S, Thadani R (2015) Complexities and controversies in Himalayan research: a call for collaboration and rigor for better data. Mt Res Dev 35(4):401-409. https://doi.org/10.1659/MRD-JOURNAL-D15-00045

Sivapalan M, Savenije HHG, Blöschl G (2012) Socio-hydrology: a new science of people and water. Hydrol Process 26(8):1270-1276. https://doi.org/10.1002/hyp.8426

Smith T, Bookhagen B (2018) Changes in seasonal snow water equivalent distribution in high mountain Asia (1987 to 2009). Sci Adv 4(1):e1701550. https://doi.org/10.1126/sciadv.1701550

Suryawanshi KR, Bhatnagar YV, Redpath S, Mishra C (2013) People, predators and perceptions: patterns of livestock depredation by snow leopards and wolves. J Appl Ecol 50(3):550-560. https://doi.org/10. 1111/1365-2664.12061

Takeda S, Yamaguchi T (2015) Changing land use and water management in a Ladakhi village of northern India. Agriculture and Agricultural Science Procedia 5:60-66. https://doi.org/10.1016/j. aaspro.2015.08.009

Telwala Y, Brook BW, Manish K, Pandit MK (2013) Climate-induced elevational range shifts and increase in plant species richness in a Himalayan biodiversity epicentre. PLoS One 8(2):e57103. https:// doi.org/10.1371/journal.pone.0057103

Tian L, Yao T, Gao Y, Thompson L, Mosley-Thompson E, Muhammad S, Zong J, Wang C, Jin S, Li Z (2017) Two glaciers collapse in Western Tibet. J Glaciol 63(237):194-197. https://doi.org/10.1017/jog.2016. 122

Van Loon AF, Ploum SW, Parajka J, Fleig AK, Garnier E, Laaha G, Van Lanen HAJ (2015) Hydrological drought types in cold climates: quantitative analysis of causing factors and qualitative survey of impacts. Hydrol Earth Syst Sci 19:1993-2016. https://doi.org/10. 5194/hess-19-1993-2015

Waddington H, White H, Snilstveit B, Hombrados JG, Vojtkova M, Davies P, Bhavsar A, Eyers J, Koehlmoos TP, Petticrew M, Valentine JC, Tugwell P (2012) How to do a good systematic review of effects in international development: a tool kit. Journal of Development Effectiveness 4(3):359-387. https://doi.org/10.1080/ 19439342.2012.711765

Wang S, Zhou L (2017) Glacial lake outburst flood disasters and integrated risk management in China. International Journal of Disaster Risk Science 8(4):493-497. https://doi.org/10.1007/s13753-017-0152-7

Wang S, He Y, Song X (2010) Impacts of climate warming on alpine glacier tourism and adaptive measures: a case study of Baishui Glacier No. 1 in Yulong Snow Mountain. Southwestern China Journal of Earth Science 21(2):166-178. https://doi.org/10.1007/ s12583-010-0015-2

Wang J, Wang Y, Wang S (2016) Biophysical and socioeconomic drivers of the dynamics in snow hazard impacts across scales and over heterogeneous landscape in northern Tibet. Nat Hazards 81(3): 1499-1514. https://doi.org/10.1007/s11069-015-2142-7

Wang L, Zeng Y, Zhong L (2017a) Impact of climate change on tourism on the Qinghai-Tibetan Plateau: research based on a literature review. Sustainability 9(1539). doi https://doi.org/10.3390/su9091539

Wang S, Wang X, Chen G, Yang Q, Wang B, Ma Y, Shen M (2017b) Complex responses of spring alpine vegetation phenology to snow cover dynamics over the Tibetan Plateau, China. Science of the Total
Environment 593-594:449-461. https://doi.org/10.1016/j.scitotenv. 2017.03.187

Wangchuk K, Wangdi J (2018) Signs of climate warming through the eyes of yak herders in northern Bhutan. Mt Res Dev 38(1):45-52. https://doi.org/10.1659/MRD-JOURNAL-D-17-00094.1

Wei Y, Wang S, Fang Y, Nawaz Z (2017) Integrated assessment on the vulnerability of animal husbandry to snow disasters under climate change in the Qinghai-Tibetan Plateau. Glob Planet Chang 157: 139-152. https://doi.org/10.1016/j.gloplacha.2017.08.017

Wesselink A, Kooy M, Warner J (2017) Socio-hydrology and hydrosocial analysis: toward dialogues across disciplines. Wiley Interdiscip Rev Water 4(2):e1196. https://doi.org/10.1002/wat2.1196

Whiteman PTS, May N (1985) The mountain environment: an agronomist's perspective with a case study from Jumla, Nepal. Mt Res Dev 5(2):151-162. https://doi.org/10.2307/3673254

Yang Y, Hopping KA, Wang G, Chen J, Peng A, Klein (2018) Permafrost and drought regulate vulnerability of Tibetan Plateau grasslands to warming. Ecosphere 9(5). https://doi.org/10.1002/ecs2.2233

Yao T, Thompson L, Yang W, Yu W, Gao Y, Guo X, Yang X, Duan K, Zhao H, Xu B, Pu J, Lu A, Xiang Y, Kattel DB, Joswaik D (2012) Different glacier status with atmospheric circulations in Tibetan Plateau and surroundings. Nat Clim Chang 2(9):663-667. https:// doi.org/10.1038/nclimate1580

Yeh ET, Nyima Y, Hopping KA (2014) Tibetan pastoralists' vulnerability to climate change: a political ecology analysis of snowstorm coping capacity. Hum Ecol 42(1):61-74. https://doi.org/10.1007/s10745013-9625-5

You QL, Ren GY, Zhang YQ, Ren YY, Sun XB, Zhan YJ, Shrestha AB, Krishnan R (2017) An overview of studies of observed climate change in the Hindu Kush Himalayan (HKH) region. Adv Clim Chang Res 8(3):141-147. https://doi.org/10.1016/j.accre.2017.04. 001

Yuan L, He Y (2006) Impacts of Yulong mountain glacier on tourism in Lijiang. J Mt Sci 3(1):71-80. https://doi.org/10.1007/s11629-0060071-3

Zhang J, Shen X (2011) Debris-flow of Zelongnong Ravine in Tibet. J MT. Sci 8:535-543. https://doi.org/10.1007/s11629-011-2137-0

Zhang W, Zhang G, Liu G, Li Z, Chen T, An L (2012) Diversity of bacterial communities in the snowcover at Tianshan number 1 glacier and its relation to climate and environment. Geomicrobiol J 29(5):459-469. https://doi.org/10.1080/01490451.2011.581329

Zhang G, Yao T, Xie H, Wang W, Yang W (2015) An inventory of glacial lakes in the Third Pole region and their changes in response to global warming. Glob Planet Chang 131:148-157. https://doi.org/10.1016/ j.gloplacha.2015.05.013

Zhao L, Ding R, Moore JC (2014) Glacier volume and area change by 2050 in high mountain Asia. Glob Planet Chang 122:197-207. https://doi.org/10.1016/j.gloplacha.2014.08.006

Publisher's note Springer Nature remains neutral with regard to jurisdictional claims in published maps and institutional affiliations. 